\title{
The Effect of "Sinar Purnama" Badui Art on Social Life of the People of Banjarharjo Village, Kulon Progo
}

\author{
Okta Sanjarwati Priutami ${ }^{1, *}$ Trie Hartiti Retnowati* \\ ${ }^{1}$ Graduate School of Arts Education Yogyakarta State University Yogyakarta, Indonesia \\ *Corresponding author oktasanjarwati@gmail.com
}

\begin{abstract}
As the era goes by, Badui art has emerged with various variations as a form of defense to preserve. The history of Badui art tells about the journey of an Islamic religious leader named Abdul Qadir Jaelani. This art was developed in the village of Banjarharjo, Kalibawang sub-district, Kulon Progo District which influenced by Badui art from Bligo village, Magelang District. Changes in the form of the presentation of this art occur slowly, little by little, and planned that is influenced by factors within and outside the community. The existence of this artistry has an influence on society to eliminate the boundaries of the layers of society, so that the community has a soul of a) mutual cooperation; b) cooperation and c) mutual respect. In the present, the Badui arts are supported by the younger generation who are directly involved in the arts in order to implement regeneration that loves their own culture. The forms of performance include name, performers, dance movements, accompaniments, makeup and clothing, showtimes, and venues. Banjarharjo Badui art has a form of presentation similar to Badui Bakalan, although there are some new variations, but it is not much different from the original form.
\end{abstract}

Keywords: change, form of presentation

\section{INTRODUCTION}

Indonesia has a variety of cultures that exist throughout the archipelago. Culture can be interpreted as something that will increase the level of knowledge including the system of ideas in the human mind. It is essentially abstract and is found in everyday life. Humans create culture in the form of tangible objects for helping their social life.

In relation to this, art is one element that is inseparable from culture. It is part of the culture of human life. Art (Indonesian: Kesenian) comes from the Sanskrit word "Sani" which means offerings, services or gifts, while in Dutch, it is derived from the word Genie, and in Latin Genius, meaning an extraordinary ability brought from birth. According to Kayam, art is one of the elements that supports culture and develops according to the conditions of that culture [3]. Therefore, we can conclude that art is the entire work of human beings on earth. Almost all processes and works on this earth are related to art, so when it is in the brink of extinction, life is also threatened. As the time goes by, art needs to be maintained and developed because the its influence is very strong on people's lives. Some of the tangible benefits of art include being used as a tool to unite community members and without art, life certainly will be harmonious. Art can also play a role as da'wah (Islamic preaching) media when Islamic values are incorporated. Overall, art can play an important role as entertainment and propaganda media, as was the case with Sunan Kalijaga (one of the nine revered saints of Islam in the island of Java) using art as a tool for his da'wah [1].

Humans can create various forms of art. Based on its nature, art is divided into three: a) fine art, b) motion art, and c) sound art. From this, we can see that dance is a type of motion art as it accentuates the motion of limbs, with or without instruments, with specific goals and functions. Dance movements are different from daily movements such as running, walking, or exercising. According to its type, dance is classified into three: a) folk dance, b) classical dance, and c) new creation dance. Forms of popular dance art include: Badui, Kubrasiswa, Jathilan, Panjidor, Incling, and many others. Almost every region in the archipelago has a folk dance. Folk dance is an art that develops in the community and cannot be separated from its social life. It is also often referred to as traditional art. Sutiyono argues that traditional art has lived for a long time, having been passed down and developed in a certain location [6]. A folk dance or traditional dance is, therefore, a dance that develops, exists, and is supported by people both in rural and urban areas.

The Badui art is one of the folk dances developed in Sleman and Magelang regencies. Apart from being used as a means of entertainment, it is also used for da'wah purposes because it also recalls an Islamic story. At some point, the Badui art was introduced in the village of Banjarharjo, Kalibawang subdistrict, Kulon Progo Regency. In this area, it is used for entertainment purposes in large events, such as recitals, community celebrations, marriages, and circumcisions. Considering its history, the Badui art initially functioned as a symbol of Islam by Abdul Qadir Jaelani, a well-known figure fighting in the name of Islam.

\section{LITERATURE REVIEW}

\subsection{Badui Art}

Art emerges and results in the form of the works of art, one of the elements that foster culture and that develop according to the conditions of that culture [3]. This art is in the form of a dance specifically classified as traditional folk dance. It is performed by a number of dancers in pairs. It has such characteristics as dynamic, energetic, and relatively free from 
any rigid rules. Nevertheless, some typical gestures or postures are often retained.

\subsection{Social Change}

Changes occurring in society can be in various kinds, one of which is social change. It is part of cultural change [4]. Gillin and Gillin in Soekanto defines social change as a variation of the way of life that has been accepted, both due to changes in geographical conditions, material culture, population composition, ideology, diffusions or new discoveries in society [4].

\subsection{The Forms of Social Change}

Social changes can be categorized into:

\subsubsection{Slow and Fast Changes}

Soekanto revealed that changes that occur for quite a long time accompanied by a series of small changes following each other slowly are called evolution. Evolution occurs by itself without any specific plans or wills [4].

On the other hand, rapid changes related to the basic life of the community (social institutions) are commonly called revolutions, according to Soekanto [4].

\subsubsection{Small and Big Changes}

Small changes are changes in the elements of social structure that do not have a direct effect.

On the contrary, major changes have a direct effect on society on elements of social structure.

\subsubsection{Intended/planned changes and unintended/unplanned changes.}

Planned changes are changes that have been prepared in advance by a particular party wishing to make these changes. The party is called an agent of change, which means a person or a group of people chosen as the leader of one or more social institutions as controllers or supervisors.

Unintended/unplanned changes taking place outside the control of the community can cause unintended social consequences.

\subsection{Factors Causing Social Changes}

In general, according to Soekanto, causes of social changes can come from within and outside the community [4].

\subsubsection{Internal Factors:}

\subsubsection{Increase or decrease in population}

Factors caused by birth and death

\subsubsection{New innovations}

New innovations are triggered by a number of things such as

a) Self-awareness of each individual or a group of people about the weaknesses of their culture

b) The quality of experts in culture

c) Stimulating creativity

\subsubsection{Community conflict}

Social conflict that is influenced by differences in interests, thoughts and views found in a community.

\subsubsection{External Factors:}

\subsubsection{Causes originating from the physical environment}

Humans often experience natural disasters. This is sometimes caused by their own actions.

\subsubsection{Influences from the cultures of other societies.}

Changes in society due to the cultures from other societies exerting its influence [4]

\subsection{Factors Influencing the Process of Change}

\subsubsection{The driving factors consist of:}

a) Contacts with other cultures

b) Advanced formal education systems

c) Appreciations for one's work and desires for progress

d) Open stratification systems

e) Heterogeneous populations

f) Community dissatisfactions with certain aspects of life

g) Future orientations

h) Values on why humans should always improve their lives [4].

\subsubsection{Barrier factors consist of:}

a) Poor relations with other communities

b) Slow developments of science

c) Ultra traditional communities

d) Strong interests

e) Fear of compromising cultural integrity

f) Prejudices against something new or strange (closedminded)

g) Ideological barriers

h) Customs or habits [4].

\subsection{The Forms of Presentation}

The forms of presentation are defined as the embodiment of various dance elements namely motion, space, and time, which together achieve aesthetic vitality. Without these elements the unity will not be accomplished. Here, the whole becomes more meaningful than the sum of its parts. The unification process then creates a form called a dance composition [2].

\section{METHOD}

This research used a qualitative research method. It aims to deeply understand the Badui art. The data collected were analyzed descriptively. The qualitative research method is often called a naturalistic technique because it is done in a natural setting [5].

The data were collected from literatures on social and artistic change, the Badui art groups, field notes, and documentary videos. 
The data, both oral and written, were collected through the following techniques: 1) Literature study relating to social and arts; 2) In-depth interviews with the head of the Badui Banjarharjo art, Mr. Zubakri, the Badui Banjarharjo art member who was also involved as an art performer, Mr. Samiyo, the Duwet Banjarharjo hamlet, Mr. Ristiyanta, and also the person in charge of the Badui Bakar Bakalan who had also been trained as an art performer, Mr. Samiyo, and also the person in charge of the Badui Bakalan trainer who had trained in Banjarharjo. Mr. Suharyanta; 3) Observation by identifying and formulating problems. Direct observations were made in the research setting where the researcher actively participated by visiting art groups; 4) Documentations in the form of previous videos of the Badui art taken in 2011 as well as photos and videos of the Badui Bakalan art to compare the differences between the two.

The data validity test was carried out using data triangulation and after that, it was compared with the data from participants. If both are the same, this research can be considered to be valid. The data analysis was performed by analyzing data on historical aspects of the birth of the Badui people and the influence of art on their social life in the Banjarharjo village, Kalibawang, Kulon Progo. The conclusion drawn from the data was done by evaluating the influence of the Bedui art on the social life of the Banjarharjo community, Kalibawang, Kulon Progo.

\section{RESULTS AND DISCUSSION}

\subsection{The History of the Badui People of Banjarharjo}

The Badui people flourished in Banjarharjo, Kalibawang, Kulon Progo. The heterogeneity of people's lives is very obvious. Geographically, the village of Banjarharjo borders the northern area of the village of Banjaroya, east of Magelang Regency, south of Sleman Regency and west of Banjar Asri village.

The history of the Badui people of Banjarharjo is inseparable from the journey of an Islamic religious leader named Abdul Qadir Jaelani. On his way, he met a group of Badui people who confronted him until a battle ensued in the group. Therefore, the art was given the name the Badui art.

Apart from the Badui history, this art first developed in Bakalan, Bligo, Magelang region before finally entering Banjarharjo village because the people there were interested in the art. At that time, the village of Banjarharjo did not yet have any arts, so this art was the main attraction for the community. This art functions as a bond between young people and as a medium of youth activities. The first time Banjarharjo community witnessed this show was more or less in 1961 during the inauguration of a bridge connecting Kulon Progo and Sleman. Since then, the village of Banjarharjo developed the art. The distance between the two regions is only around $6 \mathrm{~km}$.

Social changes in Banjarharjo society, which are influenced by the geographical location of the two regions, triggered cultural changes, one of which related to the cultural elements. The art that developed in Banjarharjo changed gradually through five periods as follows.
Table 1 Development of Badui Art in Banjarharjo

\begin{tabular}{|l|l|c|}
\hline \multicolumn{1}{|c|}{ Period } & Year & Stages \\
\hline Period I & $1961-1970$ & Introduction \\
\hline Period II & $1970-1980$ & Development \\
\hline Period III & $1980-2000$ & Vacuum \\
\hline Period IV & $2000-2008$ & Revival \\
\hline Periode V & 2008-present & Introduction of Badui Putri \\
\hline
\end{tabular}

\subsection{Changes in the Village of Banjarharjo}

\subsubsection{The forms of changes occuring in "Sinar Purnama" Badui art are:}

\subsubsection{Slow social changes}

The Badui art is changing slowly because it occurs for quite a long time from its introduction to its development, adjusting to the social situation including people's supports and oppositions towards the art.

\subsubsection{Small social changes}

Changes occurring in this art are considered as small because they only happened in the elements of social structure, not bringing any direct or meaningful influences to the community. Changes occured only in the aspects of the art, not to the community or institutions.

\subsubsection{Intended or planned changes}

Changes occurring in this art are predicted or planned by those who want to make changes about the artistic aspects. This party is called the agent of change.

\subsubsection{Factors causing changes in the "Sinar Purnama" Badui art include:}

\subsubsection{The increase or decrease in population}

The increase and decrease in population are caused by birth and death rates. Over the years, the people who were involved in the Badui art grew older, making them unable to be directly involved in the art. Some of them have died, slightly hampering the development of the art. In addition, the art management also needs to carry out regeneration activities for this development to take place.

\subsubsection{New innovations}

Along with the changing times, the management is required to maintain the art with innovations in the form of creating all forms of presentation so that the art looks more relevant.

\subsubsection{Community conflicts}

Conflicts caused by differences in community perceptions about the function of the Badui art and people's understanding of customs in Banjarharjo. For example, there are those who agree with the use of the Badui performances in Syukuran (a gathering to express a gratitude to God), but there are also those who reject it. 


\subsubsection{External factors}

\subsubsection{Causes originating from the physical environment}

In 2010, Merapi volcano erupted, impacting Bedouin art activities in Banjarharjo. The village was located near the volcano, forcing its people to improve their environment first in the aftermath of the eruption.

\subsubsection{Influences from cultures from other societies}

Many types of art began to emerge with more interesting presentations. This is an obstacle faced by the Badui art group.

\subsubsection{Factors affecting the process of change are driven by:}

a) The Banjarharjo community was affected by the spread of culture from Bakalan in the form of the Badui art. Its spread sparked new innovations in the form of initiatives to study the art.

b) The background of the people in Banjarharjo enabled many ideas to emerge for advancing the Badui art.

c) The Banjarharjo community has a sense of respect for the work that was once created, thus spurring the enthusiasm to rise from its vacuum.

d) People who have education and power determine which direction the art will be taken to.

e) The Banjarharjo community made innovations in the presentation in order to reattract people's attention.

f) The community made an nitiative to develop art by showing the art at festivals.

g) The community motivated themselves to achieve better things.

\subsubsection{Factors affecting the Badui art in the life of the Banjarharjo village community}

\subsubsection{Social Stratification}

The Badui art in Banjarharjo is influenced by the social stratification in the village, evidenced by the involvement of village officials in the Badui art, showing that there are no longer any distances between ordinary people and village officials. This illustration shows that the Badui art gives a positive impact in removing the boundaries of the social strata.

\subsubsection{Social Attitudes}

The mutual cooperation has an impact on uniting the Banjarharjo community as reflected in their collaborations in implementing discipline and training schedules. Thus, the practices run in the right manner and the community can blend, regardless of their age and background for the continuity of the art.

\subsubsection{Religious Values}

This art contains religious values. The majority of Muslims are increasingly motivated to recite songs with Islamic nuances. The Badui art, which is the symbol of the Islamic religion, makes the community, which was originally still passive in worship, become more obedient in worship.
Regeneration that occurs in this art shows that the learning process of the community in terms of appreciating and preserving traditional arts through the cultivation of the attitude of the younger generation to appreciate their own culture.

\subsection{The Forms of Presentation}

Based on the form of presentation, the Badui art of Banjarharjo consists of:

\subsubsection{Name}

In Banjarharjo, this Badui art is named "Sinar Purnama" which means the moonlight. This art serves to spread Islam through entertainment or performances.

\subsubsection{Performers}

In every show, the Badui art of "Sinar Purnama" is usually performed by both male and female dancers in their own male and female groups with a minimum of 16 people. This art is displayed in pairs so that the number of dancers always adjusts to suit their needs. In this art there is no age classification because both young and old can get involved in the art

\subsubsection{Dance movements}

The dance movements are rigid, broken, full of enthusiasm, strong and dominated by jumping motions. They symbolize people who are at war through particular gestures. The movements follow the music produced by tambourine and qasida. In each lyric, the movements change but there is a repetition of motions before the qasida lyrics change. The change of the movement is signaled by the sound of a drum and whistle. The are 30 movements in one show. The are no differences between the movements performed by male dancers and those by female dancers.

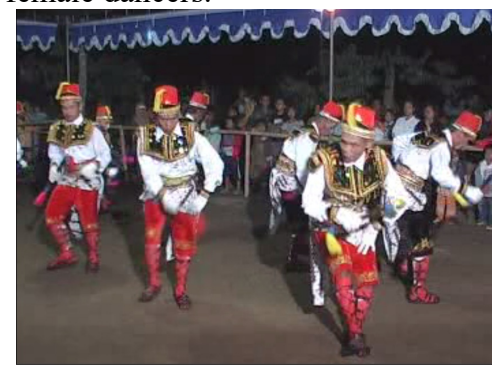

Figure 1 The dance movements of Badui Banjarharjo

\subsubsection{Accompaniments}

The accompaniment music used for the dance consists of a drum and three people singing qasida.

\subsubsection{Educational Values}


Example of the lyrics

\author{
WAHAI TEMAN \\ (HI, FRIENDS) \\ Wahai Teman Temanku Sekalian \\ (Hi, all of my friends) \\ Mari Mengabdi Kepada Kepada Tuhan \\ (Let's serve God) \\ Yang Menciptakan Semua Alam \\ (Who has created the entire universe) \\ Mudah Mudahan Tuhan Melindungi \\ (Hopefully God will protect us) \\ Dari Segala Godaan Syaithoni \\ (From the temptations of the devils) \\ Yang Merasa Dalam Hati Sanubari
}

(That we feel in our heart)

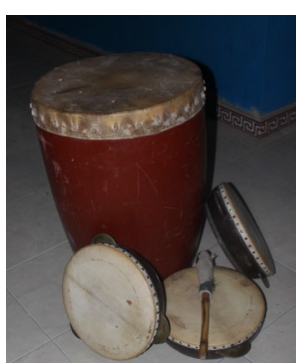

Figure 2 Musical Instruments of the Badui of Banjarharjo

\subsubsection{Makeup and Clothing}

The makeup used in the Badui group, both for male and female dancers as well as music players, only uses simple makeup powder.

The dancers wear white long-sleeved tops, banner pants, vests, jarik (batik garment), kupluk or kanigaran (traditional headdress), hat trims, wristbands, stagen (cloth wrapped around the stomach), belts or slepe and socks.

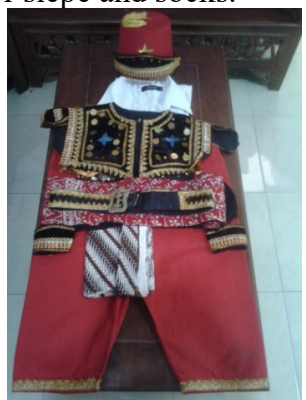

Figure 3 Clothing of the Badui of Banjarharjo

\subsubsection{Showtime}

The show is performed usually at night from 9 p.m. until 1 a.m. In a performance, there can be several rounds of dance lasting around 45-60 minutes.

\subsubsection{Venue}

The venue is usually a large arena, such as a field or stage that can accommodate up to 25 people.

\subsubsection{Awards}

Banjarharjo have won several festivals by performing the Badui art.

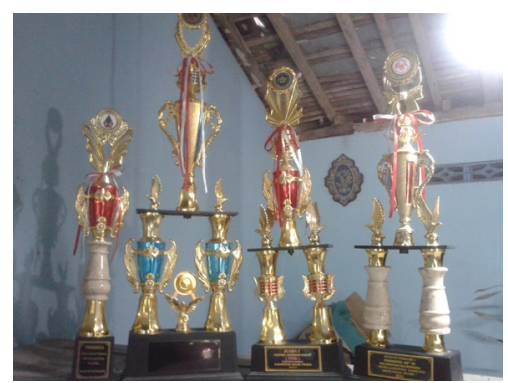

Figure 4 The trophies received by Banjarharjo village

\section{CONCLUSION}

The Badui art reflects the history of the journey of a Muslim religious man named Abdul Qadir Jaelani. The "Sinar Purnama" Badui art currently growing in Banjarharjo, Kalibawang, Barat Progo was originally from Bakalan, Bligo, Magelang. The art was adopted in 1964 because the Banjarharjo community was interested in it. This art aimes to strengthen the relationship among youth and it has been welldeveloped to this day. It can be concluded that the history of this art is influenced by the geographical area of Banjarharjo region which borders Magelang region. Cultural change was evolving slowly because it occurs for a long time from its introduction to the eventual development, with all kinds of supports and oppositions in the process. In addition, the changes are also considered to be small as they only affected aspects of the art. The changes are considered to be intended or planned (by several parties).

These changes are influenced by factors that come from within the society which include a) increase and decrease in population, b) new innovations, and c) conflicts. Meanwhile, factors that come from outside the community include: a) environmental change, and b) the cultural influences from other communities. In addition, factors influencing the process of change in the "Sinar Purnama" Badui art are driven by: a) contacts with other cultures, b) advanced formal education systems c) respects for one's work and desires for progress, d) community dissatisfactions with specific areas of life, e) heterogeneous populations, f) orientations toward the future, and g) the values that a human being should always strive to improve. Factors affecting the Badui art in the social life of Banjarharjo villagers are: a) social stratification, b) social attitudes, c) religious values, and d) educational values. In terms of performance, the Banjarharjo Badui art includes names, performers, dance movements, accompaniments, makeup and clothing, showtimes, venues, and awards ever achieved.

\section{REFERENCES}

[1] A. Imron Abu, Sunan Kalijaga Kadilangu Demak [ [Sunan Kalijaga Kadilangu Demak]". Penerbit Menara: Kudus, 1992.

[2] Turner, Margery J. "New Dance: Pendekatan Koreografi Nonliteral." Yogyakarta: Manthili (2007)

[3] Kayam, Umar. Seni, tradisi, masyarakat [Art, tradition, society]. No. 3. Penerbit Sinar Harapan, 1981.S.

[4] Soekanto, Soerjono, and Budi Sulistyowati. Sosiologi Suatu Pengantar (Edisi Revisi) [Sociology: An Introduction (Revised Edition)]." Jakarta: Raja Grafindo Persada (2013). 
[5] Sugiyono, Memahami Penelitian Kualitatif [Understanding Qualitative Research]. "Bandung: Alfa Beta, 2012, cet."
[6] Sutiyono, Puspawarna Seni Tradisi dalam Perubahan Sosial Budaya [Puspawarna Art of Tradition in SocioCultural Change]". Penerbit Kanwa Publisher: Yogyakarta, 2009 